\title{
Effects of land use and topographic variables on distribution of pine mistletoe (Viscum album subsp. austriacum (Wiesb.) Vollm.) in northeastern Turkey
}

\author{
Ayhan Usta ${ }^{1 * i \mathrm{D}}$, Murat Yılmaz ${ }^{1 \mathrm{iD}}$
}

${ }^{1}$ Karadeniz Technical University, Trabzon, Turkey

FOREST ECOLOGY

\section{ABSTRACT}

Background: This study evaluated the distribution of pine mistletoe in Scots pine ecosystems in relation to topographic variables and land uses. A total of 109 sample plots were selected from pure Scots pine forests in the Eastern Black Sea Region of Turkey. The 6-class dwarf mistletoe rating was used for infection severity. Pearson correlation analysis results showed significant relationships between mistletoe infection severity and topographic variables in $30 \mathrm{~m}$ buffer and land use in $500 \mathrm{~m}$ buffer.

Results: Of the sample plots, 69 (63\%) were mistletoe infected, and 40 (37\%) were uninfected. The t-test results showed that there was a significant difference between mean topographic variables and land use in mistletoe infected and uninfected sample plots. The results of the binary logistic regression analysis showed that altitude, productive forest, slope, and road distance were the most significant predictors of the distribution of pine mistletoe as topographic variables and land uses..

Conclusion: The common direction of mistletoe infected areas, in addition to Scots pine ecosystems, was low altitudes, sheltered valleys, more humid areas and different land use (agriculture, road and stream).

Keywords: Digital elevation model, forest, parasitic plants, moisture, terrain

\section{HIGHLIGHTS}

Land use and topographic variables of infected and uninfected plots showed significant differences. Topographically, mistletoe distribution increased at low altitudes, sheltered valleys and more humid areas. In terms of land use, the agricultural area and road/stream density-proximity increased mistletoe infection. Productive forest, road distance, slope and altitude were the most significant predictors of infected areas.

USTA, A.; YILMAZ, M. Effects of land use and topographic variables on distribution of pine mistletoe (Viscum album subsp. austriacum (Wiesb.) Vollm.) in northeastern Turkey. CERNE, v. 27, e-102618, doi: 10.1590/01047760202127012618 


\section{INTRODUCTION}

Parasitic plants are a common component of many terrestrial communities and have ecological and economic importance due to their distribution across the world (Musselman and Press, 1995; Press and Phoenix, 2005; Agrios, 2005; Mathiasen et al., 2008). More than 4.500 species of parasites are plants (Nickrent et al., 1998). This group of parasites includes plants, grasses, shrubs, and trees that receive water and nutrients from a wide variety of host plants in ecosystems worldwide (Musselman and Press, 1995). In forest ecosystems, there are some semi-parasitic plants living in many plant species (Norton et al., 2002), including mistletoe (Viscum album L.), which is a semi-parasitic plant with a wide distribution (Barlow, 1983; Watson, 2001). Mistletoe is one of the biotic factors that usually cause forest depletion in regions with moderate to severe water deficit (Tsopelas et al., 2004; Dobbertin et al., 2005). Mistletoes are semi-parasitic plants that receive water and carbohydrate from host trees (Glatzel and Geils, 2009) and contribute to biodiversity since their fruits feed several bird species in winter (Mathiasen et al., 2008). Scots pine (Pinus sylvestris L.), which is a coniferous tree with the largest geographical distribution in the world, is the host of European pine mistletoe (Zuber, 2004).

Pines are undoubtedly the most important tree species in the world. Large forests and forest lands extending along the Northern Hemisphere are covered with pine trees from subtropical to subarctic latitudes and from coastal plains to mountainous areas and high plateaus (Richardson et al., 2007). Scots pine is one of the important tree species with economic value in the world. This importance is due to the fact that this tree species builds large forests in pure and mixed forms, and its wood is valuable. Furthermore, the possibility of using its wood due to its feature to make a smooth, full, and long trunk significantly increases the economic aspect of Scots pine (Alemdağ, 1967). It was indicated that the mortality rate of Scots pines infested by mistletoe was more than twice compared to non-infested trees and that the trees containing mistletoe are among the most vulnerable individuals exposed to stress (Dobbertin and Rigling 2006). Pine mistletoe grows in a dry and moisture-free environment due to the increasing loss of needles and increases the risk of drought-related mortality by making trees more susceptible to drought stress (Rigling et al., 2010). Mistletoe infestation does not directly lead to tree death; however, its presence in a tree increases the effect of drought and strongly decreases the ability to absorb carbon in dry conditions. The trees with mistletoe suffer a loss in sap flow and storage systems, and the only way to survive this loss is to reduce their transpiration by closing their stomas. This is probably a successful mechanism against tree death without hydraulic degradation in the short term; however, it increases the risk of carbon starvation and death in the long-term (Zweifel et al., 2012). In general, a strong correlation is observed between the death of trees and the mistletoe infestation rate (Tsopelas et al., 2004, Dobbertin and Rigling, 2006; Idžojtić et al., 2008; Oliva and Colinas 2010).

The trees in settlement areas, compared to natural areas, grow under more stressful conditions, which may make them more susceptible to parasite infections, such as mistletoe. In the studies on the floristic composition of the roadside vegetation cover, it was stated that the abundance of mistletoe (Loranthaceae) in roadside trees increased (Lamont and Southall, 1982; Reid, 1997; Norton and Stafford Smith, 1999). In addition to the fragmented structure of forest ecosystems, changing the land structure due to uncontrolled tree cuttings and the replacement of natural vegetation with exotic species may allow for the formation of mistletoe.

Riparian ecosystems may also provide a sheltered haven for birds since the conditions in land conditions (water and food availability) deteriorate during periods of environmental stress (such as drought) (Nix, 1993; Morton et al., 1995). When the relationships between a mistletoehost tree and host tree-mistletoe birds are examined, the distribution of mistletoes is not dependent on the distribution of host trees (Watson, 2009). The presence of mistletoe in different areas is limited to the biotic characteristic of the species and quality of the host tree (Zuber, 2004), including abiotic limitations of temperature and water availability in mistletoe growth (Zuber, 2004) and a wide range of biotic factors on the land scale affecting the abundance and movement of bird dispensers (RodríguezCabal et al., 2007; García et al., 2009; MacRaild et al., 2010).

Dwarf mistletoes are particularly spread by an "explosive fruit" system, including both hydrostatic and mechanical mechanisms (Hawksworth and Wiens 1996). Variables affecting the spread and intensification of dwarf mistletoes in conjunction with both the explosively disseminated seed mechanism and random spread by seeds sticking to animal vectors, have been reported by several investigators (Hawksworth and Wiens, 1996; Mathiasen, 1996). These two mechanisms contribute distinctly to the dispersal of dwarf mistletoes, the first producing principally localized intensification and the second contributing to the occasional establishment of new infection areas (Mathiasen, 1996).

The aim of this study is to investigate the effects of topographic variables and land use on the distribution and infection severity of pine mistletoe in Scots pine ecosystems in Northeast Turkey.

\section{MATERIAL AND METHODS}

\section{Study area}

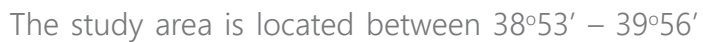
eastern longitudes and $39^{\circ} 50^{\prime}-40^{\circ} 45^{\prime}$ northern latitudes in the northeast of Turkey (Fig. 1). The study was carried out in Scots Pine forests on a total area of 5,718.8 $\mathrm{km}^{2}$.

The study area is within the boundaries of Gümüșhane province. The average altitude of the study area ranges between 1,003 $\mathrm{m}-2,228 \mathrm{~m}$. The study area, which is located within the boundaries of the Eastern Black Sea Region of the Black Sea Region, cannot fully feel the effect of the sea since the mountains in the Black Sea are parallel to the sea. The effect of the sea entering along the Harșit River and Kelkit River passing through the lower basin section of the region near Torul is slightly felt. In the study area, the annual average temperature is $9.7^{\circ} \mathrm{C}$, and the total annual precipitation is $462.1 \mathrm{~mm}$ (Tab. 1).

The vegetation structure is composed of Scots pine (Pinus sylvestris L.), Nordmann fir (Abies nordmandiana), 


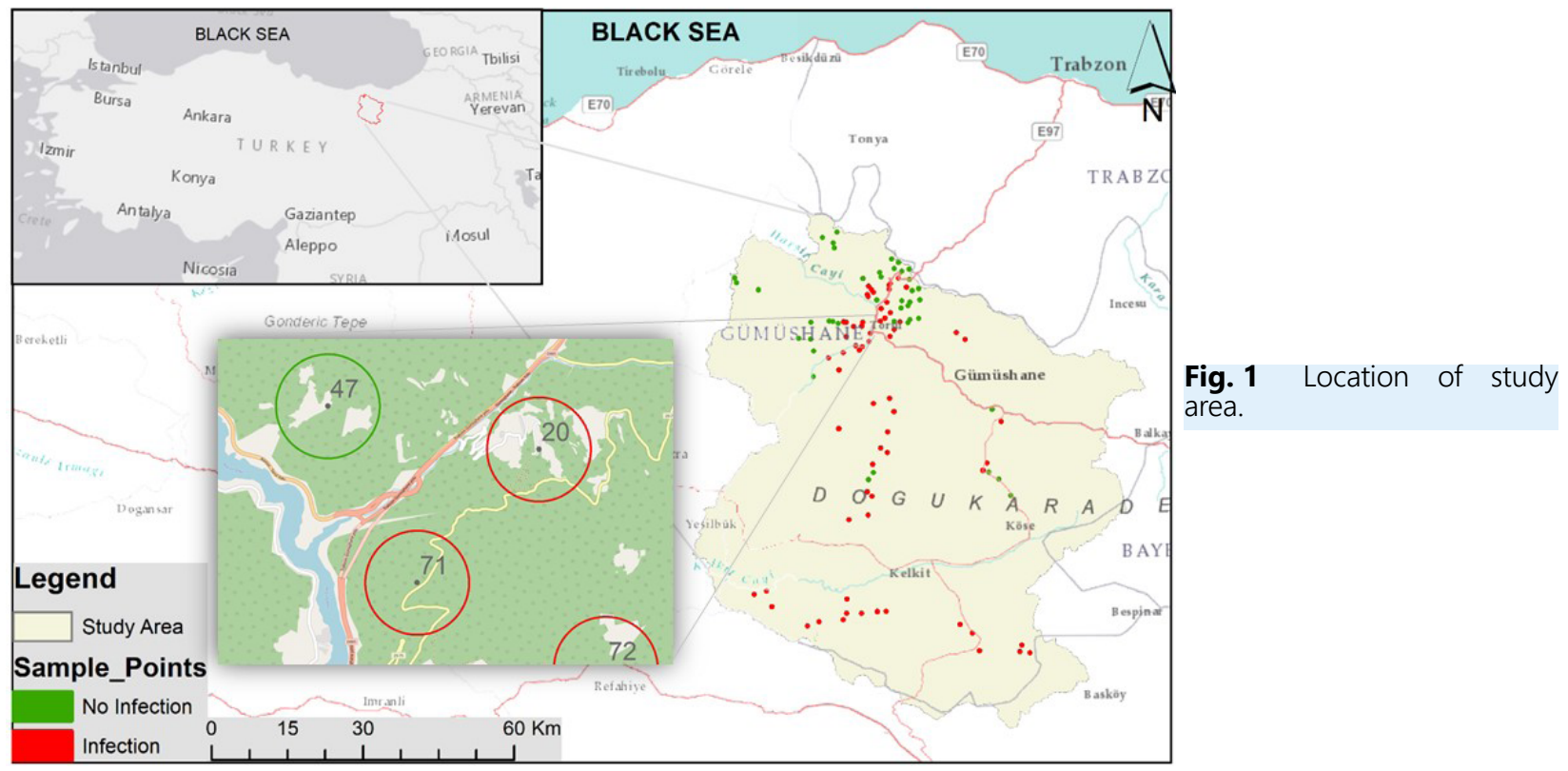

Tab. 1 Climate data of Gümüșhane meteorology station (TSMS, 2020).

\begin{tabular}{cccccccccccccc}
\hline Climate Parameters & I & II & III & IV & V & VI & VII & VIII & IX & X & XI & XII & Annual \\
\hline Temperature $\left({ }^{\circ} \mathrm{C}\right)$ & -1.7 & -0.4 & 3.8 & 9.4 & 13.7 & 17.2 & 20.2 & 20.3 & 16.7 & 11.4 & 5.1 & 0.5 & 9.7 \\
Max. temperature $\left({ }^{\circ} \mathrm{C}\right)$ & 2.8 & 5.0 & 9.8 & 16.1 & 21.0 & 24.9 & 28.1 & 28.8 & 25.3 & 18.6 & 10.5 & 4.7 & 16.3 \\
Min. temperature $\left({ }^{\circ} \mathrm{C}\right)$ & -5.6 & -5.0 & -1.1 & 3.7 & 7.6 & 10.6 & 13.7 & 13.8 & 10.0 & 5.8 & 0.7 & -3.1 & 4.3 \\
Sunshine duration $(\mathrm{h})$ & 1.3 & 3.7 & 5.0 & 6.0 & 7.4 & 9.0 & 10.0 & 9.7 & 7.9 & 5.4 & 2.2 & 0.8 & 68.4 \\
Number of rainy days & 11.0 & 10.7 & 12.6 & 13.8 & 15.6 & 10.3 & 4.0 & 3.6 & 5.4 & 9.5 & 10.1 & 11.5 & 118.1 \\
Monthly total Precipitation $(\mathrm{mm})$ & 36.2 & 32.3 & 43.5 & 60.4 & 68.2 & 46.8 & 12.1 & 12.9 & 21.7 & 45.1 & 41.9 & 41.0 & 462.1 \\
\hline
\end{tabular}

Oak (Quercus spp.) and Juniper (Juniperus spp.) species. Field studies were conducted in pure Scots pine-dominated areas.

\section{Data acquisition and processing}

The Digital Elevation Model (DEM) was used produced by Shuttle Radar Topography (SRTM GL1, Global 30, Publication Date: 04/01/2013) (SRTM, 2013). The DEM had a resolution of $30 \mathrm{~m}$. These spatial resolutions determined the scale at which the analysis was carried out and the types of patterns and processes that could be distinguished. The DEM were geo-referenced by the supplier. The elevation values of the DEM were rounded to integers, resulting in 1-m intervals (GLCF, 2006). The DEM map was used to derive the topographic variables and environmental indices (altitude, slope, radiation index, exposure to east and north, topographic position index and site exposure index) (Tab. 2 and Fig. 2). For topographic variables, a $30 \mathrm{~m}$ buffer $(0.2827$ ha) was drawn to 109 sample points. Topographic variables of 109 sample plots were determined by taking the average of the data corresponding to the pixels in the buffer area.

\section{Land use}

The forest stand type map of the forest management plans (GDF, 2006; GDF, 2013; GDF 2016) of Gümüșhane and Torul Forestry Management in the ArcGIS database were used as data. A buffer with a radius of $500 \mathrm{~m}$ was placed to 109 sample points in the GIS database for land use data. The ratio of land uses (agricultural, grassland-pasture, degraded forest, productive forest) within the buffer zone (78.5 ha) was determined as a percentage (\%). The stream layer in the study area was created in the Spatial Analyst Tools (Hydrology) module in the ArcGIS program. A road (Forest, Road) layer management plan was obtained from digital forest stand type maps, and furthermore, the road layer was derived from the ArcGIS program Basemap database. The lengths of the roads and streams over the buffer zone were used as stream density (stream length/buffer zone) and road density (road length/buffer zone). The road distance and stream distance variables representing the distance to road and stream with sample points were determined in the GIS database.

\section{Measurement of mistletoe infection severity}

A total of 109 circular sampling plots, each measuring $1,000 \mathrm{~m}^{2}$, were established using a $2 \times 2 \mathrm{~km}$ grid system in the study area. Very young stands ( $\mathrm{dbh}<20 \mathrm{~cm}$ ) and open areas lacking trees were not sampled (Bilgili et al., 2020). Mistletoe infection intensity in trees were determined. The 6-class dwarf mistletoe rating system (DMR) was used to determine the amount and intensity of mistletoe on the tree (Hawksworth,1977; Hawksworth and Wiens, 1996; Trummer et al., 1998; Hoffmann et al., 2007; Çatal and Carus, 2011). In the system, infection intensity is determined by considering 6 classes (Hawksworth, 1977). In the method, the whole crown is divided into three parts, and each part is assigned an infection rating of 0,1 or 2 (Fig. 3). According to this 
Tab. 2 Topographic variables and ecological meanings.

\begin{tabular}{cccc}
\hline Acronym & Variables & Ecological Importance & Description \\
\hline ALT & Altitude & Temperature, moisture, $\mathrm{CO}_{2}$ pressure. & Solar radiation, terrain stability, soil moisture. \\
$\mathrm{SL}$ & Slope & Altitude above sea level (m). & Slope in percent. \\
$\mathrm{RI}$ & Radiation Index & Solar radiation and precipitation. & $\begin{array}{c}\text { North-northeast (the coolest and wettest), south- } \\
\text { southwest (the hotter-dryer). From } 0 \text { to } 1 .\end{array}$ \\
NORTH & Northern exposure & Summer and winter solar radiation. & Relation to north (1 to -1$).$ \\
EAST & Eastern exposure & Morning/afternoon solar radiation, wind, & Relation to east $(1$ to -1$)$
\end{tabular}

\begin{tabular}{ccc} 
TPI & $\begin{array}{c}\text { Topographic } \\
\text { Position Index }\end{array}$ & Soil moisture and erosion, wind exposure. \\
SEI & Site Exposure Index & Soil moisture, solar radiation. \\
\hline
\end{tabular}

tpi $>0$ (ridge), tpi < 0 (valley), tpi $\sim 0$ (constant slope, flat area, or saddle).

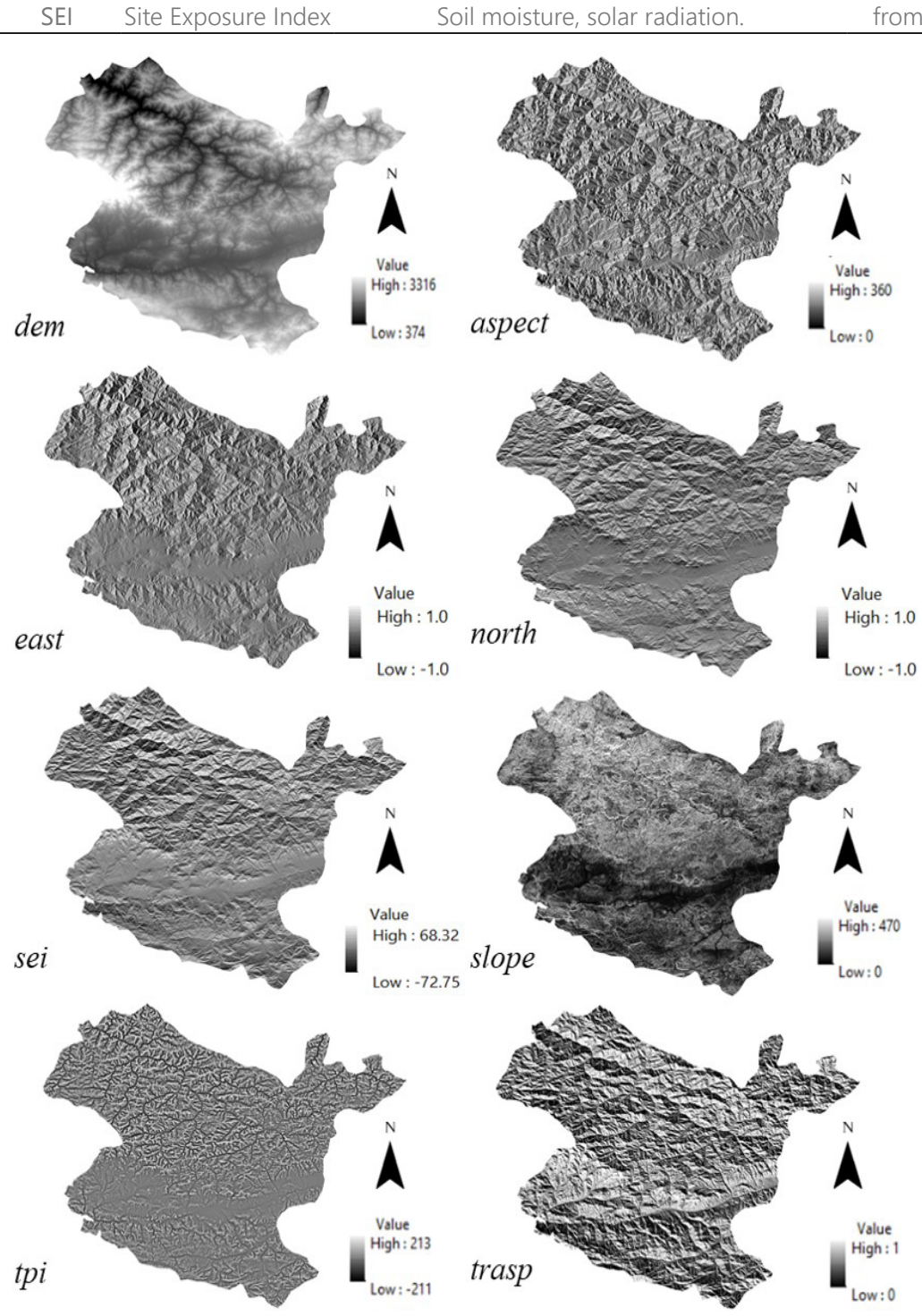

system, 0 shows no infection, $1<50 \%$ infection and $2>$ $50 \%$ infection of the branches in the respective part. For a total per-tree DMR, all values of the parts are summed (Hawksworth 1977; Hawksworth and Wiens 1996). In this study, average mistletoe infection values calculated for all sample plots were used.

\section{Statistical analyses}

Pearson correlation analysis was undertaken to investigate the relationships between mistletoe infection severity, buffer land use and topographic variables. Buffer land use and topographic variables used in the analyses are set out in Tab. 2. An independent samples t-test was used to determine whether there was a significant difference between the means of buffer land use and topographic variables of infected and uninfected Scots pine stands $(P<0.05)$. Before the analyses, a normality test was conducted on all variables. Binary logistic regression was used to estimate the probability of mistletoe infection 
using measured explanatory variables of buffer land use and topographic variables. Logistic regression models were developed based on the binary response variable (1: Mistletoe infected; 0: Uninfected stands) and some explanatory variables. The logistic regression models are defined as [1], where $p$ is the probability of mistletoe infection at Scots pine stands; $E(Y)$ is the expected value of the binary dependent variable $Y ; \beta_{0}$ is the constant to be estimated, $\beta_{i}$ is the predicted coefficient of each independent variable (Schneider and Pontius, 2001). All analyses were performed using statistical package of SPSS version 22.0 (IBM, 2013).

$\rho=E(Y)=\frac{\exp \left(\beta_{0}+\beta_{1} X_{1}+\beta_{2} X_{2}+\ldots+\beta_{i} X_{i}\right)}{1+\exp \left(\beta_{0}+\beta_{1} X_{1}+\beta_{2} X_{2}+\ldots+\beta_{i} X_{i}\right)}$

\section{RESULTS}

\section{Mistletoe distribution}

In the study area, 69 (63.3\%) of the 109 sample areas were infected with mistletoe. In this study, it was observed that the average mistletoe infection values varied between 0.00-1.81. Descriptive statistics of land use and topographic variables are presented in Tab. 3.

In general, the mean values of topographic variables (except for east and north) were higher in uninfected stands in comparison to mistletoe-infected stands. The mean values of land use (except for pasture and forest road density) were lower in uninfected stands in comparison to mistletoe-infected stands (Tab. 3).

The t-test results showed that there was a significant difference between land use and topographic variables for infected and uninfected plots. Except for slope (SL), site exposure index (SEI), exposure to east (EAST), exposure to north (NORTH), pasture (PST) and forest road density (FDE) parameters, all mean values of land use and topographic variables were significantly different in infected and uninfected plots $(p<0.01$ and $p<0.05)$. In percentage changes from uninfected sample plots, while altitude $(A L T)$, radiation index $(R I)$, road distance $(R D I)$, stream distance (SDI) and productive forest (PF) showed negative changes, topographic position index (TPI), agriculture $(A G R)$, degraded forest (DF), road density (RDE), total road density (TDE) and stream density (SDE) showed positive changes (Tab. 4).

The Pearson correlation analysis indicated significant relationships between mistletoe infection severity and topographic variables and land use. For topographic variables, mistletoe infection severity had a negative correlation with altitude $(r=-0.455, p<0.01)$, topographic position index $(r=-0.204, p<0.05)$, topographic solar radiation index $(r=-0.219, p<0.05)$, stream distance $(r=-0.258, p<0.01)$ and road distance $(r=-0.237, p<0.05)$ (Fig. 4). For buffer land use, mistletoe infection severity had a positive correlation (except for productive forest) with agriculture $(r=0.333, p<0.01)$, road density $(r=0.384$, $p<0.01)$, total road density $(r=0.416, p<0.01)$ and stream density $(r=0.240, p<0.05)$. Mistletoe infection severity had a negative correlation with productive forest $(r=-0.232$, p<0.05) (Fig. 4).

\section{Prediction of mistletoe infection using logistic}

Logistic regression was used to investigate whether the probability of mistletoe infection could be predicted using land use and topographic variables. A logistic regression analysis, four regression models were developed for mistletoe infection. Prediction percentages of logistic regression models ranged from 70.6 to 85.3 (Tab. 5)

The results of the logistic regression model (Step 4) indicated that the probability of mistletoe infection could be predicted by such land use and topographic variables as productive forest (Wald $=5.565, d f=1$ ), road distance (Wald=2.014, df=1), slope (Wald=5.615, $d f=1$ ) and altitude (Wald=15.300, df=1) (Tab. 6).

\section{DISCUSSION}

In this study, the distribution of pine mistletoe was evaluated in Scots pine stands in relation to buffer (500 m)

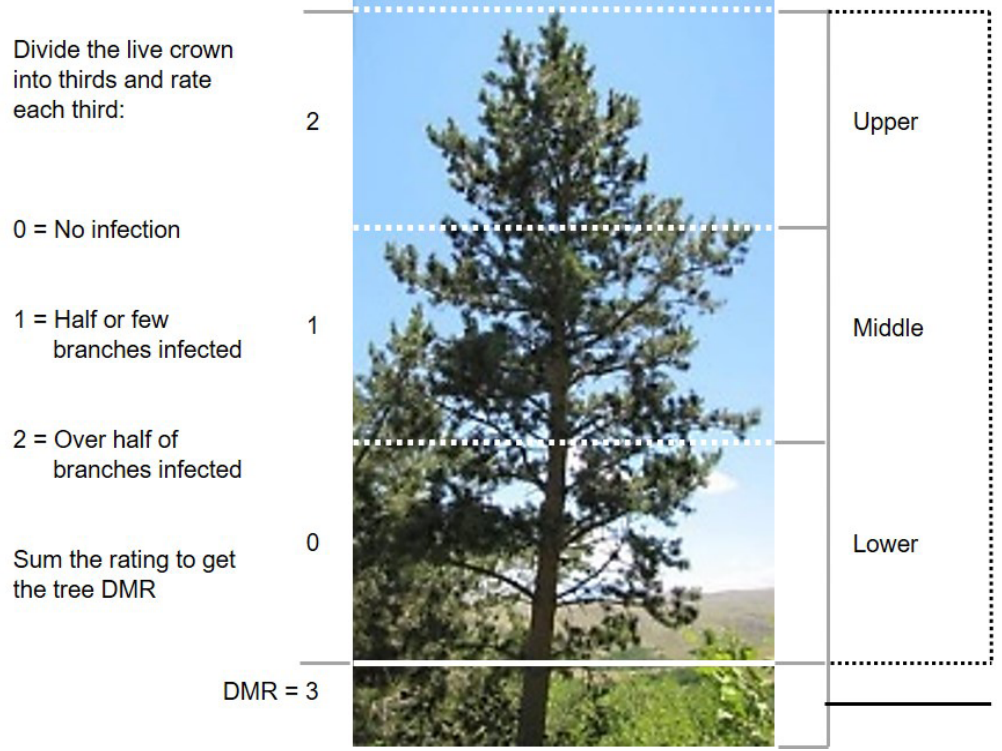

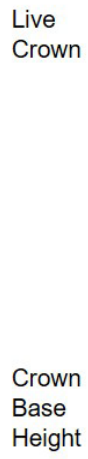

Fig. 3 Dwarf mistletoe rating in a sampled tree.
Crown
Base
Height

CERNE (2021) 27: e-102618 
Tab. 3 Descriptive statistics of land use and topographic variables of the sampled plots. For land use and topographic variables: Infected stands $(n=69)$ and uninfected stands $(n=40)$.

\begin{tabular}{|c|c|c|c|c|c|c|c|c|}
\hline & \multicolumn{4}{|c|}{ Infected stands } & \multicolumn{4}{|c|}{ Uninfected stands } \\
\hline & Min & Max & Mean & SE & Min & Max & Mean & SE \\
\hline \multicolumn{9}{|l|}{ Topographic variables } \\
\hline Altitude (m) & 1003 & 1965 & 1487 & 32.2 & 1209 & 2228 & 1762 & 39.3 \\
\hline Topographic position Index & -117.0 & 85.0 & -24.9 & 4.3 & -91.0 & 81.0 & -5.4 & 7.3 \\
\hline Slope (\%) & 10.0 & 83.0 & 45.5 & 2.3 & 10.0 & 97.0 & 52.1 & 2.8 \\
\hline Site exposure & -43.0 & 38.0 & -3.2 & 2.3 & -38.0 & 38.0 & 0.3 & 3.0 \\
\hline Radiation index & 0.01 & 0.98 & 0.39 & 0.04 & 0.01 & 0.99 & 0.53 & 0.05 \\
\hline Exposure to east & -0.72 & 0.70 & 0.00 & 0.04 & -0.70 & 0.78 & -0.03 & 0.06 \\
\hline Exposure to north & -0.78 & 0.94 & 0.06 & 0.05 & -0.76 & 0.79 & -0.01 & 0.06 \\
\hline Road distance (m) & 0.0 & 238.8 & 70.4 & 6.4 & 0.0 & $3,357.5$ & 392.4 & 129.0 \\
\hline Stream distance $(\mathrm{m})$ & 0.0 & 1278.0 & 324.1 & 36.5 & 13.0 & $1,381.0$ & 466.6 & 49.9 \\
\hline \multicolumn{9}{|l|}{ Land use (500 m buffer) } \\
\hline Agriculture (\%) & 0.0 & 59.2 & 13.0 & 1.5 & 0.0 & 42.7 & 5.6 & 1.6 \\
\hline Pasture (\%) & 0.0 & 52.9 & 11.7 & 1.9 & 0.0 & 72.6 & 12.6 & 2.7 \\
\hline Degraded forest (\%) & 0.0 & 100.0 & 33.0 & 3.0 & 0.0 & 67.4 & 18.4 & 2.7 \\
\hline Productive forest (\%) & 0.0 & 98.8 & 42.4 & 3.0 & 0.0 & 99.4 & 63.4 & 4.0 \\
\hline Road density $\left(\mathrm{m} \cdot \mathrm{ha}^{-1}\right)$ & 0.00 & 66.83 & 15.33 & 1.61 & 0.00 & 37.05 & 6.53 & 1.60 \\
\hline Forest road density $\left(\mathrm{m} \cdot \mathrm{ha}^{-1}\right)$ & 0.00 & 35.86 & 12.14 & 1.35 & 0.00 & 46.16 & 13.57 & 1.98 \\
\hline Total road density $\left(\mathrm{m} \cdot \mathrm{ha}^{-1}\right)$ & 11.10 & 133.67 & 42.81 & 2.67 & 0.00 & 74.10 & 26.63 & 3.22 \\
\hline Stream density $\left(m \cdot h a^{-1}\right)$ & 0.00 & 24.52 & 8.58 & 0.82 & 0.00 & 20.23 & 5.10 & 1.05 \\
\hline
\end{tabular}

land use and topographic variables. In response to mistletoe infection severity measured in sample plots, land use and topographic variables were derived from forest stand type maps and the digital elevation model (DEM) map, respectively. Prediction percentages of logistic regression models ranged from 70.6 to 85.3 (Tab. 5). The results of the logistic regression model (Step 4) indicated that the probability of mistletoe infection could be predicted by such land use and topographic variables as productive forest (PF), road distance (RDI), slope (SL) and altitude (ALT) (Tab. 6). The study provides a different perspective on the distribution of mistletoe infection.

\section{Effects of topographic variables on mistletoe distribution}

A total of 109 circular sampling plots, each measuring $1000 \mathrm{~m}^{2}$, were obtained using a $2 \times 2 \mathrm{~km}$ grid system in the study area. In the study area, 69 (63.3\%) of the 109 sample plots were infected with pine mistletoe. The fact that $63.3 \%$ of the sample areas are infected with pine mistletoe provides important information about the future of Scots pine ecosystems in the research area. The Pearson correlation analysis indicated significant relationships between mistletoe infection severity, topographic variables and land use. For topographic variables, mistletoe infection severity had a negative correlation with altitude $(r=-0.455$, $p<0.01)$, topographic position index $(r=-0.204, p<0.05)$ and topographic solar radiation index $(r=-0.219, p<0.05)$ (Fig. 4). Bilgili et al. (2020) reported that mistletoe infection severity had a negative correlation with altitude $(r=-0.469$, $\mathrm{p}<0.01)$. The difference in correlation in altitude was due to both the number of sample plots (109 sample plots) and the digital elevation model (DEM) data.

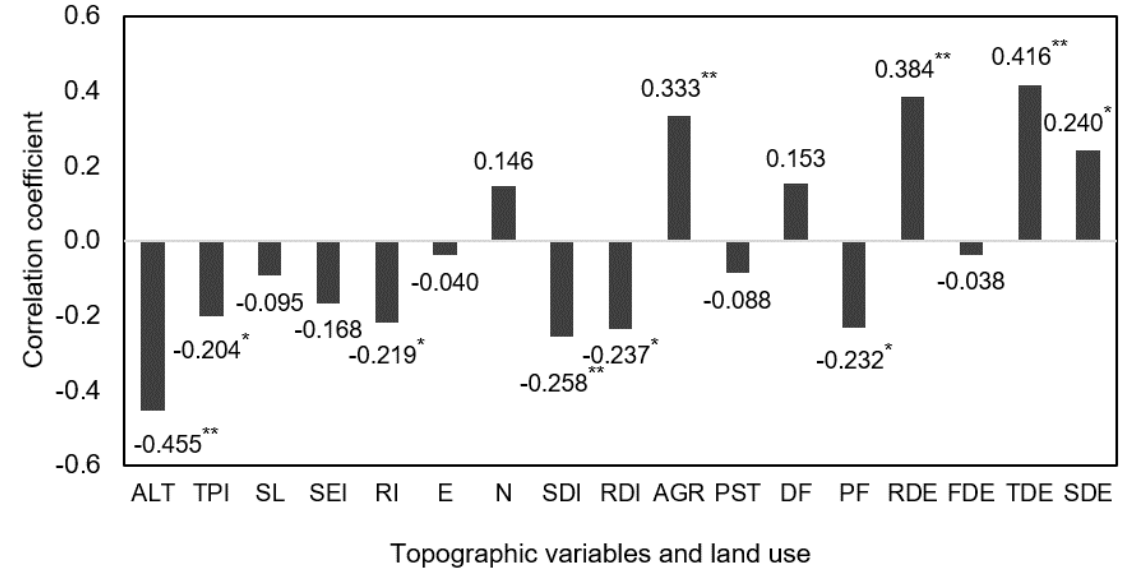

ALT: Altitude, TPI: Topographic position index, SL: Slope, SEI: Site exposure index, RI: Radiation index, E: Exposure to east, N: Exposure to north, SDI: Stream distance, RDI: Road distance, AGR: Agriculture, PST: Pasture, DF: Degraded forest, PF: Productive forest, RDE: Road density, FDE: Forest road density, TDE: Total road density, SDE: Stream density, ${ }^{* *}$ Correlation is significant at the 0.01 level (2-tailed); * Correlation is significant at the 0.05 level (2-tailed)
Fig. 4 Correlations between infection severity and topographic variables and land use. 
Tab. 4 Land use and topographic variables of Scots pine under mistletoe infection.

\begin{tabular}{|c|c|c|c|c|c|c|}
\hline Parameters & Acronym & Status & Mean & SE & Effect $(p)$ & Percent change \\
\hline \multicolumn{7}{|l|}{ Topographic variables } \\
\hline Altitude (m) & ALT & $\begin{array}{l}\text { Uninfected } \\
\text { Infected }\end{array}$ & $\begin{array}{l}1762 \\
1487\end{array}$ & $\begin{array}{l}39.30 \\
32.22\end{array}$ & $0.000^{*}$ & -18.5 \\
\hline Topographic position index & TPI & $\begin{array}{l}\text { Uninfected } \\
\text { Infected }\end{array}$ & $\begin{array}{l}-5.40 \\
-24.91\end{array}$ & $\begin{array}{l}7.34 \\
4.27\end{array}$ & $0.015^{\star}$ & 78.3 \\
\hline Slope (\%) & SL & $\begin{array}{l}\text { Uninfected } \\
\text { Infected }\end{array}$ & $\begin{array}{l}52.05 \\
45.46\end{array}$ & $\begin{array}{l}2.82 \\
2.30\end{array}$ & 0.079 & -14.5 \\
\hline Site exposure index & SEI & $\begin{array}{l}\text { Uninfected } \\
\text { Infected }\end{array}$ & $\begin{array}{c}0.30 \\
-3.24\end{array}$ & $\begin{array}{l}2.99 \\
2.33\end{array}$ & 0.355 & 109.3 \\
\hline Radiation index & $\mathrm{RI}$ & $\begin{array}{l}\text { Uninfected } \\
\text { Infected }\end{array}$ & $\begin{array}{l}0.53 \\
0.39\end{array}$ & $\begin{array}{l}0.05 \\
0.04\end{array}$ & $0.033^{*}$ & -33.8 \\
\hline Exposure to east & EAST & $\begin{array}{l}\text { Uninfected } \\
\text { Infected }\end{array}$ & $\begin{array}{l}-0.03 \\
0.00\end{array}$ & $\begin{array}{l}0.06 \\
0.04\end{array}$ & 0.621 & 1189.5 \\
\hline Exposure to north & NORTH & $\begin{array}{l}\text { Uninfected } \\
\text { Infected }\end{array}$ & $\begin{array}{l}-0.01 \\
0.06\end{array}$ & $\begin{array}{l}0.06 \\
0.05\end{array}$ & 0.386 & 110.1 \\
\hline Road distance (m) & RDI & $\begin{array}{l}\text { Uninfected } \\
\text { Infected }\end{array}$ & $\begin{array}{c}392.41 \\
70.40\end{array}$ & $\begin{array}{c}128.98 \\
6.40\end{array}$ & $0.001^{*}$ & -457.4 \\
\hline Stream distance $(\mathrm{m})$ & SDI & $\begin{array}{l}\text { Uninfected } \\
\text { Infected }\end{array}$ & $\begin{array}{l}466.55 \\
324.07 \\
\end{array}$ & $\begin{array}{l}49.88 \\
36.53 \\
\end{array}$ & $0.022^{*}$ & -44.0 \\
\hline \multicolumn{7}{|l|}{ Land use (500 m buffer) } \\
\hline Agriculture (\%) & AGR & $\begin{array}{l}\text { Uninfected } \\
\text { Infected }\end{array}$ & $\begin{array}{c}5.61 \\
12.99\end{array}$ & $\begin{array}{l}1.63 \\
1.54\end{array}$ & $0.002^{*}$ & 56.8 \\
\hline Pasture (\%) & PST & $\begin{array}{l}\text { Uninfected } \\
\text { Infected }\end{array}$ & $\begin{array}{l}12.60 \\
11.68\end{array}$ & $\begin{array}{l}2.71 \\
1.88\end{array}$ & 0.775 & -7.9 \\
\hline Degraded forest (\%) & DF & $\begin{array}{l}\text { Uninfected } \\
\text { Infected }\end{array}$ & $\begin{array}{l}18.42 \\
32.97\end{array}$ & $\begin{array}{l}2.69 \\
2.95\end{array}$ & $0.001^{*}$ & 44.1 \\
\hline Productive forest (\%) & PF & $\begin{array}{l}\text { Uninfected } \\
\text { Infected }\end{array}$ & $\begin{array}{l}63.37 \\
42.36\end{array}$ & $\begin{array}{l}4.00 \\
3.01\end{array}$ & $0.000^{*}$ & -49.6 \\
\hline Road density $\left(m \cdot h a^{-1}\right)$ & RDE & $\begin{array}{l}\text { Uninfected } \\
\text { Infected }\end{array}$ & $\begin{array}{c}6.53 \\
15.33\end{array}$ & $\begin{array}{l}1.60 \\
1.61\end{array}$ & $0.000^{*}$ & 57.4 \\
\hline Forest road density $\left(\mathrm{m} \cdot \mathrm{ha}^{-1}\right)$ & FDE & $\begin{array}{l}\text { Uninfected } \\
\text { Infected }\end{array}$ & $\begin{array}{l}13.57 \\
12.14\end{array}$ & $\begin{array}{l}1.98 \\
1.35\end{array}$ & 0.539 & -11.8 \\
\hline Total road density $\left(\mathrm{m} \cdot \mathrm{ha}^{-1}\right)$ & TDE & $\begin{array}{l}\text { Uninfected } \\
\text { Infected }\end{array}$ & $\begin{array}{l}26.63 \\
42.81\end{array}$ & $\begin{array}{l}3.22 \\
2.67\end{array}$ & $0.000^{*}$ & 37.8 \\
\hline Stream density $\left(\mathrm{m} \cdot \mathrm{ha}^{-1}\right)$ & SDE & $\begin{array}{l}\text { Uninfected } \\
\text { Infected }\end{array}$ & $\begin{array}{l}5.10 \\
8.58 \\
\end{array}$ & $\begin{array}{l}1.05 \\
0.82 \\
\end{array}$ & $0.010^{*}$ & 40.6 \\
\hline
\end{tabular}

Summary statistics (means and standard error) and t-test results for the infected and uninfected stands and trees. Significance values are indicated as: ${ }^{*} \mathrm{p}$ $<0.05$ and $n s=p \geq 0.05$. Percent change is calculated from the mean values of mistletoe infected and uninfected stands

Tab. 5 Classification table.

\begin{tabular}{|c|c|c|c|c|c|}
\hline \multicolumn{6}{|c|}{ Classification table } \\
\hline & & & \multicolumn{3}{|c|}{ Predicted } \\
\hline & & & \multicolumn{2}{|c|}{ Mistletoe } & \multirow{2}{*}{ Percentage correct } \\
\hline & & & Uninfected & Infected & \\
\hline \multirow{3}{*}{ Step 1} & \multirow{2}{*}{ Mistletoe } & \multirow{3}{*}{$\begin{array}{l}\text { Uninfected } \\
\text { Infected }\end{array}$} & 21 & 19 & 52.5 \\
\hline & & & 13 & 56 & 81.2 \\
\hline & Overall percentage & & & & 70.6 \\
\hline \multirow{3}{*}{ Step 2} & \multirow{2}{*}{ Mistletoe } & \multirow{3}{*}{$\begin{array}{l}\text { Uninfected } \\
\text { Infected }\end{array}$} & 26 & 14 & 65.0 \\
\hline & & & 10 & 59 & 85.5 \\
\hline & Overall percentage & & & & 78.0 \\
\hline \multirow{3}{*}{ Step 3} & & \multirow{3}{*}{$\begin{array}{l}\text { Uninfected } \\
\text { Infected }\end{array}$} & 29 & 11 & 72.5 \\
\hline & Mistletoe & & 7 & 62 & 89.9 \\
\hline & Overall percentage & & & & 83.5 \\
\hline \multirow{3}{*}{ Step 4} & \multirow{2}{*}{ Mistletoe } & Uninfected & 29 & 11 & 72.5 \\
\hline & & Infected & 5 & 64 & 92.8 \\
\hline & Overall percentage & & & & 85.3 \\
\hline
\end{tabular}


Usta and Yilmaz

Tab. 6 Result of the binary logistic regression analysis of mistletoe infection.

\begin{tabular}{cccccccc}
\hline & Variables & B & S.E. & Wald & df & Sig. & Exp(B) \\
\hline \multirow{2}{*}{ Step 1 } & Altitude (m) & -0.004 & 0.001 & 18.388 & 1 & 0.000 & 0.996 \\
& Constant & 7.235 & 1.611 & 20.168 & 1 & 0.000 & $1,387.80$ \\
\hline \multirow{3}{*}{ Step 2 } & Productive forest (\%) & -0.029 & 0.010 & 8.877 & 1 & 0.003 & 0.971 \\
& Altitude (m) & -0.004 & 0.001 & 14.548 & 1 & 0.000 & 0.996 \\
& Constant & 8.562 & 1.867 & 21.025 & 1 & 0.000 & $5,231.08$ \\
\hline \multirow{3}{*}{ Step 3 } & Productive forest (\%) & -0.027 & 0.010 & 7.147 & 1 & 0.008 & 0.973 \\
& Slope (\%) & -0.037 & 0.015 & 6.325 & 1 & 0.012 & 0.963 \\
& Altitude (m) & -0.005 & 0.001 & 16.985 & 1 & 0.000 & 0.995 \\
& Constant & 11.766 & 2.455 & 22.974 & 1 & 0.000 & $128,745.77$ \\
\hline \multirow{3}{*}{ Step 4 } & Productive forest (\%) & -0.025 & 0.011 & 5.565 & 1 & 0.018 & 0.975 \\
& Road distance (m) & -0.004 & 0.003 & 2.014 & 1 & 0.156 & 0.996 \\
& Slope (\%) & -0.037 & 0.016 & 5.615 & 1 & 0.018 & 0.964 \\
& Altitude (m) & -0.005 & 0.001 & 15.300 & 1 & 0.000 & 0.995 \\
& Constant & 12.115 & 2.594 & 21.815 & 1 & 0.000 & $182,680.58$ \\
\hline
\end{tabular}

Altitude has a significant effect on the distribution of mistletoe because temperature is a key factor for the growth of mistletoe (Plagnat, 1950), and a negative correlation is observed between altitude and the ratio of mistletoe (Idžojtić et al., 2008; Barbu, 2009; Barbu, 2010). The highest altitude of mistletoe-infected sample plots was in 1,965 $\mathrm{m}$ (Tab. 3). This altitude was also reported by Bilgili et al. (2020). Moreover, this altitude is about $500 \mathrm{~m}$ above the former highest altitude determined for Viscum album ssp. austriacum (Dobbertin et al. 2005). T-test results showed that the average altitude of infected (1487 $\mathrm{m})$ and uninfected $(1,762 \mathrm{~m})$ sample plots were different. The altitude (ALT) variable entered all the logistic regression models and predicted mistletoe infection by $70.6 \%$ (Tab. 5-6). The studies on the intensity and occurrence of mistletoe infestation occurring in various parts of the world revealed that the spread of mistletoe was limited to low temperature, reflecting differences in the ratio and intensity of mistletoe in geographical regions (Williams, 1971). In the studies reporting several mistletoe species, the upper limits of altitude indicated that the growing season was not long enough for fruits to grow in autumn; warming would prolong the growing season and allow it to expand geographically (Dash and Hunt, 2007). Pine mistletoe, Viscum album ssp. austriacum, is defined as the very low temperature-sensitive species of three Central European mistletoe subspecies (Tubeuf, et al., 1923; Jeffree and Jeffree 1996), and in this study, low temperature is also likely to be a limiting factor for mistletoe intensity at upper altitudes.

Topographic position index (TPI) is a measure of slope position on a terrain, with lower values describing valleys or ravines and higher values describing hilltops and ridges. T-Test and correlation analysis results showed that there was no relation about SL. On the other hand, $\mathrm{SL}$ entered logistic regression models that predicted the mistletoe infection severity. The average SL was lower in mistletoe-infected sample plots (Tab. 3). A negative correlation ( $r=-0.204, p<0.05$ ) between mistletoe infection severity and TPI is an indicator that infection is in ravines and valleys rather than in hilly and ridges (Fig.4). The average TPI was lower in mistletoe-infected sample plots (Tab. 3). T-test results indicated that the average TPI of infected (-24.9) and uninfected (-5.40) sample plots were different $(p<0.05)(T a b .4)$. Ravines and valleys are humidity areas with more proximity to water. Riparian sites may also provide a sheltered haven for birds since the conditions in land conditions (e.g., food availability, water availability) can deteriorate in arid areas and periods of drought (Nix, 1993; Morton et al. 1995).

Radiation (RI) value assigns the value " 0 " to the north-northeast slopes (typically the coldest and most humid aspect) and the value " 1 " to the warmer and arid slopes in the south-southwest (Moisen and Frescino, 2002). North-northeast slopes are another factor that increases humidity. The negative correlation $(r=-0.219, p<0.05)$ between the radiation index (RI) and mistletoe infection severity also supported this result (Fig. 4). The average radiation index (RI) was lower in mistletoe-infected sample plots (Tab. 3). T-test results showed that the average RI of infected (0.39) and uninfected (0.53) sample plots were different $(p<0.05)($ Tab. 4).

\section{Effects of land use on mistletoe distribution}

Dwarf mistletoes are particularly spread by an "explosive fruit" system, including hydrostatic-mechanical mechanisms (Hawksworth and Wiens 1996). Variables affecting the spread and intensification of dwarf mistletoes, in conjunction with both the explosively disseminated seed mechanism and random spread by seeds sticking to animal vectors, have been reported by several investigators (Hawksworth and Wiens, 1996; Mathiasen, 1996). These two mechanisms contribute distinctly to the dispersal of dwarf mistletoes, the first producing principally localized intensification and the second contributing to the occasional establishment of new infection areas (Mathiasen, 1996). Moreover, the diversity and structure of vegetation affect the land plot and the presence of birds in large areas, and some forest birds prefer different environments rather than homogeneous areas (Haila et al., 1996).

In the study, a buffer with a radius of $500 \mathrm{~m}$ was drawn to the sample points to determine the heterogeneity of the land, and the land uses in the area were determined. Mistletoe infection severity had a positive correlation with agriculture $(r=0.333, p<0.01)$. However, mistletoe infection severity had a negative correlation with productive forest 
$(r=-0.232, p<0.05)$ (Fig. 4). The average agriculture (AGR) (\%) was higher in mistletoe- infected sample plots, but productive forest (PF) was lower (Tab. 3). T-test results showed that the average agriculture (AGR) of infected $(12,99 \%)$ and uninfected $(5,61 \%)$ sample plots were different $(p<0.01)$ (Tab. 4). The average productive forest (PF) of infected (42.36\%) and uninfected (63.37\%) sample plots were different $(p<0.01)$ (Tab. 4).

Land heterogeneity and vegetation structure may increase the diversity and abundance of birds within the agricultural ecosystems by increasing the number of ecological niches (Heikinnen et al., 2004; De La Montaña et al., 2006). Bare soil in agricultural ecosystems was indicated to be an important habitat component for insecticidal birds (Schaub et al., 2010). Agricultural systems that increase the structural and temporal diversity of agricultural products and natural vegetation can support the presence of wildlife in agricultural ecosystems (Kremen et al., 2012). Furthermore, the fact that the presence of streams and roads increases the heterogeneity of the land structure may support mistletoe infection.

Mistletoe infection severity had a positive correlation with both road density $(r=0.384, p<0.01)$ and total road density $(r=0.416, p<0.01)$ (Fig. 4). Both the average road density (RDE) (m/ha) and total road density (TDE) (m/ha) were higher in mistletoe- infected sample plots (Tab. 3). T-test results showed that the average road density (RDE) of infected (15.33 m/ha) and uninfected (6.53 m/ha) sample plots were different $(p<0.001)$ (Tab. 4). Moreover, the average total road density (TDE) of infected (42.81 m.ha-1) and uninfected $\left(26,63 \mathrm{~m} \cdot \mathrm{ha}^{-1}\right)$ sample plots were different $(p<0.001)$. On the other hand, the negative correlation $(r=$ $-0.237, p<0.05$ ) between road distance (RDI) and mistletoe infection severity supported this result (Figure 4). T-test results showed that the average road distance (RDI) of infected (15.33 m/ha) and uninfected (6.53 m.ha-1) sample plots were different $(p<0.001)$ (Tab. 4). However, the road distance (RDI) was included in model 4 in the prediction of mistletoe infection severity (Tab. 6).

Roadside areas are generally considered as a good habitat for mistletoe, and the absence of mistletoe indicates that fruit-dispersing birds do not use road corridors or stay long enough to collect mistletoe seeds (Norton et al., 1995). Increasing water and food availability, decreased host areas on the roadside, and increased movements of birds along the road corridor increased the formation of mistletoe in the roadside vegetation (Norton and Stafford Smith, 1999). The redistribution of resources by road rather than the effect of the road is considered as the most effective factor in the mistletoe formation model (Norton and Stafford Smith, 1999). It indicates that mistletoes are more intense in roadside habitats than vegetation cover (Lamont and Southall, 1982; Norton and Stafford Smith, 1999). In Western Australia, Lamont and Southall (1982) recorded that roadside potential host trees had 13 times more mistletoes than the adjacent nature reserve. According to forest roads, infection intensities (no, light, and severe) were statistically similar. The fact that the platform width $(4 \mathrm{~m})$ of forest roads is narrower compared to other roads and that forest roads are dirt roads mostly used for forestry activities and seasonal purposes by people indicate that forest roads are not effective in mistletoe infection. Thus, there was no statistical relationship between forest road density $(F D E)$, and mistletoe infection severity, and the t-test results supported this (Fig. 4, Tab. 4).

The correlation between mistletoe infection severity, both stream density (SDE) $(r=0.240, p<0.05)$ and stream distance (SDI) ( $r=-0.258, p<0.01$ ), was determined (Fig. 4). The SDE and SDI increased the risk of mistletoe infection. In mistletoe-infected sample plots, SDE was higher, but SDI was lower (Tab. 3). T-test results showed that the average SDE of infected $(8.58 \mathrm{~m} / \mathrm{ha})$ and uninfected $\left(5.10 \mathrm{~m} \cdot \mathrm{ha}^{-1}\right)$ sample plots were different $(p<0.05)$ (Tab. 4). Moreover, the average SDI of infected (324.07 $\mathrm{m}$ ) and uninfected (466.55 $m)$ sample plots were different $(p<0.05)$. The introduction of riparian areas as key habitats for birds is usually based on a high number of species (England et al. 1984; Décamps et al., 1987; Brown et al., 1989) and local individual (Johnson \& Haight, 1985; Szaro and Jakle, 1985; Smith and Schaefer, 1992; Mac Nally et al., 2000; Pearson and Manuwal, 2001). Riparian sites may also provide a sheltered haven for birds since the conditions in land conditions (e.g., food availability, water availability) can deteriorate in arid areas and periods of drought (Nix, 1993; Morton et al. 1995).

As a result, this study provides a major contribution to the existing knowledge on host-parasite relationship between pine mistletoe (Viscum album ssp. austriacum) distribution and Scots pine in relation to land use and topographic variables. There is a need for studies investigating the effects of these variables on mistletoe distribution in extreme (humid-arid) growing environments, particularly by using more topographic variables that can be derived from DEM.

\section{CONCLUSION}

In this study, the effects of topographic variables and land use on the distribution of pine mistletoe in semi-arid Scots pine ecosystems were investigated. Topographically, the lower altitudes, sheltered valleys, and more northnortheast areas (humid) increased the mistletoe distribution. In terms of land use, the increase of agricultural area, road density-proximity and stream density-proximity increased the distribution of mistletoe. The common direction of mistletoeinfected areas, in addition to Scots pine ecosystems, was low altitudes, sheltered valleys, more humid areas and different land use (agriculture, road and stream). All these results may show the environment preferred by the mistle thrush bird, which provides the spread of mistletoe.

\section{ACKNOWLEDGEMENTS}

This study was supported by The Scientific and Technological Research Council of Turkey, Project No: TOVAG-1120258.

\section{AUTHORSHIP CONTRIBUTION}

Project Idea: $A U, M Y$

Funding: MY, AU 
Database: AU, MY

Processing: $\mathrm{AU}$

Analysis: $\mathrm{AU}$

Writing: AU

Review: AU, MY

\section{REFERENCES}

AGRIOS, G. N. Plant pathology. Elsevier Academic Press, 2005. 952p.

ALEMDAĞ, S. Structure and yield potential of Scotch pine (Pinus sylvestris L.) forests in Turkey and the principles to be followed in managing these forests. Forest Research Institute, 1967, 160p.

BARBU, C. Impact of mistletoe attack (Viscum album ssp. abietis) on radia growth of Silver fir. A case study in the North of Eastern Carpathians. Annals of Forest Research, v. 52, n. 1, p. 89-96, 2009.

BARBU, C. The Incidence and Distribution of White Mistletoe (Viscum album ssp. abietis) on Silver Fir (Abies alba Mill.) Stands from Eastern Carpathians. Annals of Forest Research, v. 53, n. 1, p. 27-36, 2010

BARLOW, B. A. Biogeography of Loranthaceae and Viscaceae. In CALDER, M.; BERNHARDT, P. The Biology of Mistletoes. Sydney, Academic Press. 1983. p. 19-46.

BILGILI, E.; COSKUNER, K. A.; BAYSAL, I.; OZTURK, M.; USTA, Y.; EROGLU, M.; NORTON, D. The distribution of pine mistletoe (Viscum album ssp. austriacum) in Scots pine (Pinus sylvestris) forests: from stand to tree level Scandinavian Journal of Forest Research, v. 35, n 1-2, p. 20-28, 2020

BROWN, G W: EARL, G. E. GRIFFITHS, R. C: HORROCKS, G. F B : WILLIAMS L. M. Flora and Fauna of the Acheron Forest Block Central Highlands, Victoria. Ecological Survey Report. Department of Conservation, Forests and Lands, Melbourne, v. 93, n.30, p. 66-71, 1989.

ÇATAL, Y.; CARUS, S. Effect of Pine Mistletoe on Radial Growth of Crimean Pine (Pinus nigra) in Turkey. Journal of Environmental Biology, v. 32, n. 3, p. 263-270, 2011.

DASH, S.K.; HUNT, J.C.R. Variability of climate change in India. Current Science, v. 93, n. 6, p. $782-788,2007$

DE LA MONTAÑA, E.; REY-BENAYAS, J. M.; CARRASCAL, L. M. Response of bird communities to silvicultural thinning of Mediterranean maquis. Journa of Applied Ecology, v. 43, p. 651-659, 2006

DÉCAMPS, H.; JOACHIM, J.; LAUGA, J. The importance for birds of the riparian woodlands within the alluvial corridor of the River Garonne, SW France. Regulated Rivers: Research \& Management, v. 1, n. 4, p. 301-316, 1987

DOBBERTIN, M.; RIGLING, A. Pine mistletoe (Viscum album ssp. austriacum) contributes to Scots pine (Pinus sylvestris) mortality in the Rhone valley of Switzerland. Forest Pathology, v. 36, n. 5, p. 309-322, 2006.

DOBBERTIN, M.; HILKER, N.; REBETEZ, M.; ZIMMERMANN, N. E. WOHLGEMUTH, T.; RIGLING, A. The upward shift in altitude of pine mistletoe (Viscum album ssp austriacum) in Switzerland - the result of climate warming? International Journal of Biometeorology, v. 50, n. 1, p. 40-47, 2005

ENGLAND, A. S.; FOREMAN, L. D.; LAUDENSLAYER, W. F. J. Composition and abundance of bird populations in riparian systems of the California deserts. In: WARNER, R. E. HENDRIX, K. M. California Riparian Systems. University of California Press, 1984. p. 694-705

GARCÍA, D.; RODRÍGUEZ-CABAL, M. A.; AMICO, G. Seed dispersal by a frugivorous marsupial shapes the spatial scale of a mistletoe population. Journal of Ecology, v. 97, p. 217-229, 2009.

GDF. Gümüșhane, Karanlıkdere, Șiran and Kelkit forest management plans Republic of Turkey, General Directorate of Forestry, Gümüșhane Regional Directorate of Forestry, Trabzon, 2013.

GDF. Sarıçăğı, Zigana, Kürtün and Örümcek forest management plans data. Republic of Turkey, General Directorate of Forestry, Torul Regional Directorate of Forestry, Trabzon, 2016

GDF. Torul forest management plan. Republic of Turkey, General Directorate of Forestry, Torul Regional Directorate of Forestry, Trabzon, 2006. (Não encontrado Internet).

GLATZEL, G.; GEILS, B. W. Mistletoe ecophysiology: host-parasite interactions Botany, v. 87, n. 1, p. 10-15, 2009.

HAILA, Y.; NICHOLLS, A. O.; HANSKI, I. K.; RAIVIO, S. Stochasticity in bird habitat selection: year-to-year changes in territory locations in boreal forest bird assemblage. Oikos, v. 76, n. 3, p. 536-552, 1996.

HAWKSWORTH, F. G.; WIENS, D. Dwarf Mistletoes: Biology, Pathology, and Systematics. Department of Agriculture, Forest Service, 1996, 410 p.
HAWKSWORTH, F G The 6-class dwarf mistletoe rating system Department of Agriculture, Forest Service, Rocky Mountain Forest and Range Experiment Station.1977, 7p.

HEIKINNEN, R. K.; LUOTO, M.; VIRKKALA, R.; RAINIO, K. Effects of habitat cover, andscape structure and spatial variables on the abundance of birds in an agricultural - forest mosaic. Journal of Applied Ecology, v. 41, p. 824-835, 2004.

HOFFMAN, C: MATHIASEN, R: SIEG, C. H. Dwarf mistletoe effects on fuel loadings in ponderosa pine forests in northern Arizona. Canadian Journal of Forest Research, v. 37, n. 3, p. 662-670, 2007

IBM, C. IBM SSPS statistic for Windows. Version 22.0, Armonk, New York: IBM Corp, 2013.

IDŽOJTIĆ, M.; PERNAR, R.; GLAVAŠ, M.; ZEBEC, M.; DIMINIĆ, D. The incidence of mistletoe (Viscum album ssp. abietis) on silver fir (Abies alba) in Croatia. Biologia, v. 63, n. 1, p. 81-85, 2008

JEFFREE, C. E.; JEFFREE, E.P. Redistribution of the potential geographical ranges of mistletoe and Colorado beetle in Europe in response to the temperature component of climate change. Functional Ecology, v. 10, n. 5 , p. 562-577, 1996 .

JHNSON, R R : HAIGHT, L. T Avian use of xeroriparian ecosystems in the North American warm deserts. In: JOHNSON, R. R.; ZIEBELL, C. D. PATTON, D. R.; FFOLLIOTT, P.F.; HAMRE, R. H. Riparian Ecosystems and Their Management: reconciling conflicting uses. United States Department of Agriculture Forest Service, Tucson, 1985, p. 156-160.

KREMEN, C.; ILES, A.; BACON, C. Diversified farming systems: an agroecological, systems-based alternative to modern industrial agriculture. Ecology and Society, v. 17, n. 4, p. 44, 2012

LAMONT, B. B.; SOUTHALL, K. J. Biology of the mistletoe Amyema preissii on road verges and undisturbed vegetation. Search, v. 13, n. 3, p. 87-88, 1982.

MAC NALLY, R.; SODERQUIST, T.; TZAROS, C. L. The conservation value of mesic gullies in dry woodland landscapes: avian communities in the boxironbark system of southern Australia. Biological Conservation, v. 93, n. 3. p. 293-302, 2000

MACRAILD, L. M.; RADFORD, J. Q.; BENNETT, A. F. Non-linear effects of landscape properties on mistletoe parasitism in fragmented agricultural landscapes. Landscape Ecology, v. 25, n. 3., p. 395-406, 2010.

MATHIASEN, R.L. Dwarf mistletoes in forest canopies. Northwest Science, v. 70 , p. 61-71, 1996

MATHIASEN, R. L.; NICKRENT, D. L.; SHAW, D. C.; WATSON, D.M. Mistletoes: Pathology, systematics, ecology, and management, Plant Disease, v. 92, n. 7, p. 988-1006, 2008

MOISEN, G. G.; FRESCINO, T. S. Comparing five modelling techniques for predicting forest characteristics. Ecological modelling, v. 157, n. 2-3, p. 209225,2002

MORTON, S. R.; SHORT, J.; BAKER, R. D. Refugia for Biological Diversity in Arid and Semi-arid Australia. CSIRO Division of Wildlife and Ecology, Canberra, v. 4, p. 1-171, 1995

MUSSELMAN, L. J.; PRESS, M. C. Introduction to parasitic plants. In: PRESS, M. C.; GRAVES, J. D. Parasitic plants, 1995. p. 1-13.

NICKRENT, D. L.; DUFF, R. J.; COLWELL, A. E.; WOLFE, A. D.; YOUNG, N. D.; STEINER, K. E. Molecular phylogenetic and evolutionary studies of parasitic plants, In: SOLTIS, D. E. SOLTIS, P. S: DOYLE, J. Molecular systematics of plants II DNA sequencing. Kluwer Academic, 1998. p. 211-241.

NIX, H. A. Bird distributions in relation to imperatives for habitat conservation in Queensland. In: CATTERALL, C. P.; DRISCOLL, P.; HULSMAN, K. A.; TAPLIN, A. Birds and their Habitats: Status and Conservation in Queensland. 1993. p. 12-21.

NORTON, D. A : SMITH, M. S. Why might roadside mulgas be better mistletoe hosts? Australian Journal of Ecology. v. 24, n. 3, p. 193-198, 1999.

NORTON, D. A.; HOBBS, R. J.; ATKINS, L. Fragmentation, disturbance, and plant distribution: mistletoes in woodland remnants in the Western Australian wheatbelt. Conservation Biology, v. 9, n. 2, p. 426-438, 1995.

NORTON, D. A.; LADLEY, J. J.; SPARROW, A. D. Host provenance effects on germination and establishment of two New Zealand mistletoes (Loranthaceae). Functional Ecology, v. 16, n. 5, p. 657-663, 2002.

OLIVA, J.; COLINAS, C. Epidemiology of Heterobasidion abietinum and Viscum album on silver fir (Abies alba) stands of the Pyrenees. Forest Pathology, v. 40, n. 1, p. 19-32, 2010.

PEARSON, S. F.; MANUWAL, D. A. Breeding bird response to riparian buffer width in managed Pacific Northwest Douglas-Fir forests. Ecological Applications, v. 11, n. 3, p. 840-853, 2001

PLAGNAT, F. Silviculture in Fir stands infested with Mistletoe. Revue Forestiere Francaise, v. 7/8: p. 365-378, 1950.

PRESS, M. C.; PHOENIX, G. K. Impacts of parasitic plants on natural communities. New phytologist, v. 166, n. 3, p. 737-751, 2005. 
REID, N. Control of the mistletoes by possums and fire: a review of the evidence. Victorian Naturalist, v. 114, 1997. p. 149-158.

RICHARDSON, D, M: RUNDEL, P. W: JACKSON, S. T: TESKEY R O ARONSON, J.; BYTNEROWICZ, A.; WINGFIELD, M. J.; PROCHES, S. Human impacts in pine forests: past, present, and future. Annual Review of Ecology, Evolution, and Systematics, v. 38, p. 275-297, 2007.

RIGLING, A.; EILMANN, B.; KOECHLI, R.; DOBBERTIN, M. Mistletoe-induced crown degradation in Scots pine in a xeric environment. Tree Physiology, v. 30, n. 7, p. $845-852,2010$

RODRÍGUEZ-CABAL, M. A: AIZEN, M A: NOVARO, A J. Habitat fragmentation disrupts a plant-disperser mutualism in the temperate forest of South America. Biological Conservation, v. 139, n. 1-2, p. 195 202, 2007.

SCHAUB, M.; MARTINEZ, N.; TAGMANN-IOSET, A.; WEISSHAUPT N.; MAURER, M.L.; REICHLIN, T. S.; ABADI, F.; ZBINDEN, N.; JENNI, L. ARLETTAZ, R. Patches of bare ground as a staple commodity for declining ground-foraging insectivorous farmland birds. PLOS One, v. $5, n .10$ $\mathrm{e}-13115,2010$

SRTM. Shuttle Radar Topography Mission, NASA Shuttle Radar Topography Mission Global. Distributed by OpenTopography. https://doi.org/10.5069/ G9445JDF Accessed: January 23th 2020.

SZARO, R. C. JAKLE, M. D. Avian use of a desert riparian island and its adjacent scrub habitat. The Condor, v. 87, n. 4, p. 511-519, 1985
TRUMMER, L. M.; HENNON, P. E.; HANSEN, E. M.; MUIR, P. S. Modeling the incidence and severity of hemlock dwarf mistletoe in 110-year-old wind-disturbed forests in Southeast Alaska. Canadian journal of forest research, v. 28, n. 10, 1501-1508, 1998.

TSMS. Climate Data of Gümüșhane (1961 - 2019). Turkish State Meteorological Service, Ankara, Accessed: 2020-03-25, 2020

TSOPELAS, P: ANGELOPOULOS, A: ECONOMOU, A.: SOULIOTI, N. Mistletoe (Viscum album) in the fir forest of Mount Parnis, Greece. Forest ecology and management, v. 202, n. 1-3, p. 59-65, 2004

TUBEUF, K.; NECKEL, G.; MARZELL, H. Monographie der Mistel. R. Oldenburg, München und Berlin, 1923, 832p.

WATSON, D. M. Determinants of parasitic plant distribution: the role of host quality. Botany, v. 87, n. 1, p. 16-21, 2009

WATSON, D. M. Mistletoe-a keystone resource in forests and woodlands worldwide. Annual Review of Ecology and Systematics, v. 32, p. 219-249, 2001.

WILLIAMS, W. T. Distribution of three species of dwarf mistletoe on their principal pine hosts in the Colorado Rocky Mountain Front Range. Phytopathology, v. 61, p. 1324-1325, 1971

ZUBER, D. Biological flora of central Europe: Viscum album L. Flora-Morphology, Distribution, Functional Ecology of Plants, v. 199, n. 3, p. 181-203, 2004.

ZWEIFEL, R: BANGERTER, S: RIGLING, A: STERCK, F. J. Pine and mistletoes: how to live with a leak in the water flow and storage system? Journal of Experimental Botany, v. 63, n. 7, p. 2565-2578, 2012. 